\title{
FLOWS OF LABOR FORCE AND TYPES OF LABOR MARKETS IN THE TRANSITION ECONOMY
}

\author{
Venelin Terziev \\ Academician of the Russian Academy of Natural History, Moscow, Russia, \\ Prof. D.Sc. (Ec.), D.Sc. (National Security), D.Sc. (Social Activities), Ph.D., National Military \\ University, Veliko Tarnovo, Bulgaria; University of Rousse, Rousse, Bulgaria, terziev@skmat.com

\begin{abstract}
The problems of the modern labor market are subject to increasing interest in the field of research, policy discussions and management practice. They become especially topical in the years of transition and the membership of Bulgaria in the European Union, as well as the emerging new challenges facing Bulgaria in the new demographic, economic and social conditions.
\end{abstract}

Keywords: transition economy, labor markets, labor force, employers.

\section{INTRODUCTION}

In general, the labor market can be presented by the occurring processes that characterize it. They are characterized by the opposition of two quantities: potential of the labor force and needs of the labor force. Their interpretation cannot be explained unambiguously. It should be clear from the beginning that there are certain problems concerning their calculation. It is known, however, how many the employed are according to the official statistics; as offering labor, they belong to the potential and as demanding labor - to the needs. These values and their comparison would be relatively accurate. We know how the absolute number of the registered unemployed in the labor offices is, but do not know how many people are not registered as unemployed, although they are seeking employment, and on the other hand it is not absolutely certain that all registered persons are actively seeking employment. li can be concluded in general that it is possible that some unemployed persons are not registered in the labor offices because their registration seems hopeless, or because the unemployment benefits are irrelevant. In this line of conclusions, we could confirm that some „unemployed" are registered in the labor offices only to receive unemployment and social benefits (Georgiev, 2016; Georgiev, 2017-a; Terziev, Kanev, 2019).

\section{FLOWS OF LABOR FORCE AND TYPES OF LABOR MARKETS IN THE TRANSITION ECONOMY}

The tendencies in the labor market development follow the main tendencies and processes in the development of the economy in recent years - restructuring of sectors and industries, privatization of large state enterprises, liquidation of inefficient and loss-making enterprises and industries, dying out of traditional activities and the emergence of new activities, etc. Economic development is accompanied by loss of markets, shortage of raw materials and weak investment and capital. 
Many different processes taking place in the labor market can be found, that can be figuratively presented as follows (Fig.1).

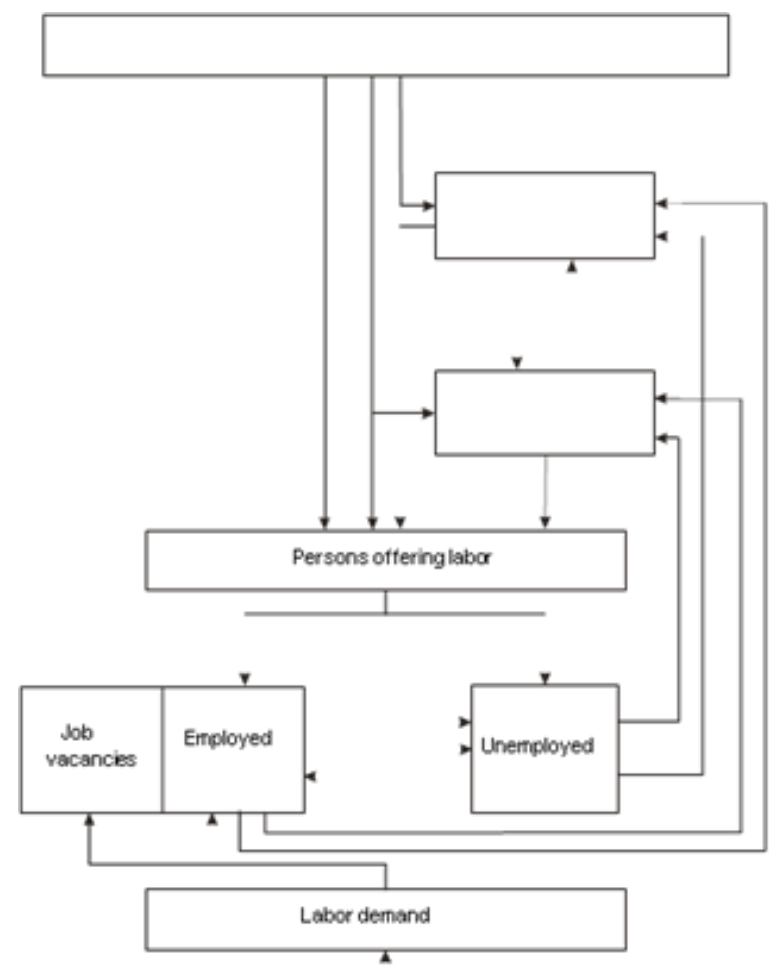

Prochuction of goods and services

Figure 1. Composition and flows of the labor market

The starting point here is the active population, which consists of all persons who are able to work and are entitled to this. This group of persons does not include: sick persons who are unable to work, as well as children whose employment is prohibited. This category should also exclude those who do not offer their labor, such as housewives or persons of retirement age, who are practically not on the active labor market. Such group is also the students who are of working age, are not in the educational system, are partially or to a smaller extent involved as an active part on the labor market. A large group of the unemployed persons offers labor, declaring part-time work opportunities, i.e. part of the working day, shift, etc (Terziev, Kanev, 2019).

Currently, Bulgaria is in situation of "excess" of labor supply, i.e. there is a too high level of unemployment (registered in the labor offices). A national economy is seeking at a certain point of time only that quantity of labor, which is optimal for it. When the labor demand is realized, the plans of those who offer work coincide with the plans of those who seek work. The plans of businesses (enterprises, companies, organizations, etc.) are not always realized and part of the labor demand cannot be met. Unoccupied job vacancies remain. The behavior of a particular person to seek work with certain quantitative and qualitative characteristics is of crucial importance.

Those who offer work and those who seek work "meet" on the labor market and "reach an agreement". On the one hand, this process starts with a job search by the able-bodied person, and on the other hand, with the relevant activity of the company. After the two subjects establish contact, they enter a discussion, i.e. perform actions leading to the conclusion of an employment contract. This would be the best way of action, but in many cases this does not lead to the conclusion of any contract (labor contract or entering of labor relations), and the reasons behind this should be clarified; in other cases despite the active contact, no contract is concluded between the parties. The analysis of these processes and actions is complex and cannot be characterized only by quantitative characteristics (Terziev, 2019a-k; Terziev, 2018-d).

The labor supply on the labor market has enough dimensions that could be considered as follows:

- Quantitative dimension - the size of the labor supply in a national economy depends on the number of able-bodied persons, as its changes shall be determined by the birth and death rates on the one hand, and 
by the net number of migrants from other countries on the other.

- Dimensions of behavior - not all working-age persons offer their labor. An appropriate measure is the probability the able-bodied person to offer their labor on the labor market. The behavior can be presented by the number of the working hours offered, and if this measure has a value equal to zero, then the person does not offer labor and the likelihood of participation is also zero. Unlike the likelihood of participation that reflects only the participation in the working life, the working hours proposed also present the size of the supply per unit of time (period).

- Qualitative dimensions - this aspect shows that the persons offering labor are heterogeneous in terms of skills and education.

- Dimension of intensity - persons offering labor who are homogeneous in their qualitative characteristics, prove to be heterogeneous in terms of the efforts invested in them.

The supply and demand for labor are the two main components of the labor market and we could not consider them separately.

The labor market is a complex system of relatively independent and interconnected markets. Depending on the selected criteria, the modern labor markets can be divided into one type or another 58 .

Depending on the sources of labor for the organization that employs the labor force, external and internal labor markets can be distinguished.

The internal labor market is the labor force market within the organization. It characterizes the policy in terms of demand and employment of workers within the company. For the job vacancies in a company with internal market part of the available employees are used after a preliminary training. The jobs, occupied by persons who are not part of the company, either correspond to the lowest and prestigious level of the career ladder, or there are no corporate employees to occupy them. Exceptions are also those jobs that require extremely high qualification and continuous training. Employment from the "external“ (primary) market is also possible when a new job position is created in the company and a change in the company's employment is impossible.

Reasons for the formation of the internal market can be:

- The need for additional labor force associated with the introduction of new equipment or technologies, new processes and products;

- The ambition of the company to refund the amounts invested in vocational education and training of the employees of the organization, as well as the resources invested to improve working conditions, social security, etc.;

- The opportunities for quick adaptation of the employee to the requirements of the policy and culture of the organization;

- The need to retain staff in the organization, reduce the turnover rate, etc.

The internal recruitment of staff contributes to: increasing the loyalty to the organization; motivation for more skilled and responsible work; raising the interest of external persons, as far as they are attracted by the possibility of success in the organization; better use of the staff in the organization, etc.

The external labor market is the market in the country. It characterizes the employment and jobs at national level. In its capacity as a distinctive mechanism for distribution and redistribution of the labor force, it is in constant dynamics and movement. The special attention to it and the need for its deep analysis are due to the fact that the processes occurring in the external market determine the level of employment and unemployment, determine the prices of different types of labor.

Spatial or geographical aspect

The labor market is limited in space and time. The demand and supply of labor always extend in certain time and limits. The geographical boundaries of the labor market are outlined by the territorial distance at which those who offer and seek work wish to extend. According to their capabilities, training and personal preferences and interests, those who offer work settle down into their area of residence in case there are job vacancies available of course. If there are no job vacancies, they change their place of work or their profession.

As a rule, people do not tend to change their place and work, especially if there are bigger opportunities for appropriate and relevant to their professional specialization work in the region. The higher the qualification 
and greater the investments in a particular profession, the greater the spatial mobility of the employees is.

From the spatial or geographical criterion's perspective, we talk about national and global labor market. We can distinguish a number of other market communities within them.

The national labor market is:

- Local labor market (urban, rural);

- Regional (district or in different regions, municipalities);

- Market at a national level.

World market that can be:

- Regional (Latin American, Eastern European, Scandinavian, etc.);

- Continental (European, Asian, etc.).

Each of these types of labor markets has specific qualities that distinguish it from the other. They also have many common features inherent to their essential characteristic, i.e. of the abstract model of the labor market. The interaction between them is predetermined by the mobility of the labor force. For its part, the mobility of the labor force is mainly and primarily associated with the cost of labor, with the statutory or other legal rights or restrictions, with the personal interest and motivation for the territorial mobility of people (emigration, immigration), with the degree of awareness of job vacancies. The motion of the labor force between the spatial lines of the separate labor markets is determined by the level of payment, working conditions and additional payment. This makes the Western European market attractive for people from less developed countries. High unemployment further increases the interest in highly developed economies.

The most limited market in terms of space is the local market. The "purchase - sale" of labor force in this market is very limited within the distance that people agree to travel without changing their place of residence. The differences in employment and salaries here are smaller. The local labor market is equally well examined by both those who supply labor and do not want to leave it, and those who seek labor and prefer to employ labor force from this market.

Unlike the local, the regional labor market covers a larger area, as the differences in employment and payment here are also larger and are due to various factors. These differences are long-lasting and the reason for this lies mainly in the lower mobility of human resources within the region. However, they are lower in the region than between the regions themselves, which leads to deep and lasting differences in the state of the labor market in the different regions of our national economy.

When the mobility of resources - the labor force, is within the territory of the country, then the lines of the labor market expand and we talk about national labor market.

If the degree of aggregation goes beyond the national borders and includes the mobility of resources - the labor force beyond the national borders, then we talk about international labor market. Depending on the geographical borders, the market may be regional (a classic example of this is the market of the European Union), and continental (European, Asian).

\section{Professional criterion}

In terms of specialization and differentiation of the labor force three groups of labor markets could be distinguished:

- Professional labor markets (skilled labor markets) where labor force with a particular profession is offered and employed: doctors, teachers, programmers and many others. The specific professional qualification which provides the mobility of the employees in sectors, companies, regions is acquired at higher education institutions. High mobility is determined not only by the relevant classification, but also by the level of remuneration, working conditions and opportunity for professional realization and development.

- Unskilled labor markets - include labor markets, where the persons who supply labor have no qualifications or have very low qualifications and low degree of education, the majority of who are unemployed. The employers in these markets do not have any special requirements for professional qualification of those who supply labor. Actually the employees are hired to carry out various, but very simple in functions and operations activities for which no preliminary training is necessary, i.e. activities that could be performed by anyone. That is why economists also call these markets "markets for all." The dominating motive for job search in these markets is the size of the salary. The high mobility of the unskilled labor markets is mainly due to the pursuit of higher remuneration, which is why those who supply labor tend to 
change their place of work more often.

- Sector (branch) labor markets - such type of labor markets where labor force with specific professional training, adequate to the requirements of a particular sector or industry is both supplied and demanded. The skills held by the employees are to serve specific industries and production and can be used only in them. These markets cover large fields, industries and sectors of the economy such as public administration, public catering, army, metallurgy, chemical industry, etc. Source of labor force for these markets are persons who have acquired the necessary training through education received in universities and other institutions, as well as the relevant qualifications they gain in the organizations themselves.

The determining factor in employment and distribution of personnel on the product markets is not the size of the salary. On these markets, those who supply labor are motivated by the nature of the work they carry out, as it corresponds to their training and job security. The requirements to those who seek job are determined by the specifics of the workplace and the internal rules of the industry, production. That is why this labor force is less mobile beyond the industry, the branch, the enterprise.

In terms of professional training and qualification of human resources, we distinguish three types of labor markets: skilled labor market, unskilled labor market and production market, where there are specific mechanisms of distribution of the labor force. On the skilled labor market, the distribution is conducted on the basis of correspondence between job requirements and professional characteristics of those who supply labor and the mechanism of remuneration. The determining factor in the distribution of production markets are the specific rules and requirements to the employees by the industry organizations. The distribution of the labor force on the unskilled labor markets is motivated mainly by the mechanism of payment. The different driving mechanisms of distribution, which operate on the three types of labor markets are "crushed by the energy" of the interacting interests of employees or employers.

We shall emphasize that the labor market is composed of numerous specialized labor markets. It has its own dimensions and lines defining the "rules of the game", which the behavior of those who supply and demand labor is submitted to. As far as the mobility of the labor force has different dimensions, the lines of the labor market are conditional.

An idea of the labor market can also be given by its elements, which taken together form its structure as a system. The structural elements of the labor market include: population; employed; unemployed; persons outside the labor force; jobs; employers; labor cost; institutional structure; infrastructure.

The population of the country is not a component of the labor market, but is a major source of labor. It is characterized by the main demographic processes - birth and death rate, which determine the natural population growth and migration (the difference between emigrants and immigrants).

The employed persons under the Methodology of the National Statistics Institute comprise persons at the age of 15 or older who:

- Perform work for the production of goods and services at least 1 hour for a salary in cash or in kind;

- Have a job but are temporarily absent due to sickness, training, adverse weather conditions, leave, etc.;

- Work in their own business, company or farm or perform other work for income;

- Persons working without payment in companies, businesses or farms of relatives of their households.

According to the social status in employment, the employees are grouped into the following groups:

- Employers and self-employed who use wage labor;

- Employees to perform a certain job for remuneration in cash or in kind;

- Unpaid family employees.

The unemployed are the persons at the age of 15 or older, who do not work for money, are looking for job and are ready to begin shortly.

Persons outside the labor market - include the persons who are not part of the labor force.

Jobs - comprise all occupied and unoccupied job vacancies in the economy.

The employers are the main subject of the labor market. They are physical or legal entity who hires workers independently.

The labor costs includes the funds which the employer is willing pay in order to hire employees. 
The Institutional structure of the labor market includes the legal framework, acts of government and of the authorized bodies; intergovernmental and other agreements regulating the behavior of employers and employees.

The infrastructure of labor market includes the organizations of the employers and employees at national, regional or local level, providing interaction between those who supply and demand labor.

The dynamics of the labor market, the intensity of its motion can be traced through the main flow of the labor force in it.

The first inflow is the one of the persons outside the labor force to the unemployed persons who are looking for job - housewives, pensioners, students, pupils, disabled people, etc.

The second flow (outflow) is the one of the employed to the unemployed persons, who are looking for job discharged, left on their own will, retired by age or disease, but kept their ability to work.

The third flow is the one of the unemployed, who are looking for paid employment to the job vacancies.

The fourth flow is the one of the employees to the job vacancies. It is composed of employed who are looking for a better job and payment.

The fifth flow is the one of the employed persons outside the labor force (those who are unemployed on their will, discharged due to expedience, laid off).

The sixth flow is the one of the unemployed persons to the persons outside the labor force.

The flows shall also include the persons who operate their own business, as well as the unpaid family employees.

The impact of the labor market on the employment and the use of human resources in the organizations is determined by its function and purpose, specifics and particular characteristics. For a given organization, the impact of the labor market is determined by the characteristics of the regional labor market; by its level of imbalance (between the supply and demand for specific types of work), and the presence and nature of work of the institutions of the labor market; by the state and regional policy in terms of employment, economic development and income per capita; by the state intervention in the functioning of the labor market, etc.

The labor market is a theoretical model but also a concrete reality for any market economy and its main subjects - the business organizations. The specific dimensions, characteristics and performance of the labor market arise from the level of development of the economy and society, the type of market economy, from the macroeconomic and social policy of the state and its level of interference in the functioning of the labor market, from the power and strategy of the trade unions, employers' organizations and other nongovernmental institutions and last but not least from the legislation in terms of economy, social security and labor relations.

Compared with other markets, the labor market has a number of characteristics that stem primarily from the specific nature of the goods, supplied and demanded there.

The distinctive features, the characteristics of the labor market are mainly related to the following:

- A commodity is offered, created over a long period of time with various investments in education, training and qualifications.

- The price that the one who offers the production factor "labor" wants to receive on the market is related to the need to provide a return on investment on its preparation; to be relevant to its quality (education, training, qualification and skills); to ensure the already reached standard of living and even higher - both personal and the one of the family; to provide opportunities for recovery, professional development and social security (for temporary and long-term disability), etc. This price may be provided by both the basic remuneration and the additional allowances and bonuses to it, by various benefits, holidays, leisure, professional training and qualifications, etc.

- The employers are looking for a commodity - in this case the production factor "labor" that is not disposable and that is the main production factor.

- The price which the person seeking the commodity of "labor" is willing to pay, is determined by their preliminary assessment (in the process of recruitment and selection) for the productivity of the commodity of "labor", for the contribution of its bearer (the labor force, which represents the current economic active population) to the profit and efficiency, the integration and adaptation of the employed in the team, for their contribution to the development and image of the organization, etc. 
- The price, which the person seeking the commodity of "labor" offers, is also predetermined by their financial resources, competitiveness, degree of substitutability of labor and capital.

The labor market is a mechanism for distribution of labor, human resources, regulator of employment, of the balance between the supply and demand for labor. From this perspective, it is a factor with an extremely strong impact on human resources management, its functions and activities (remuneration, planning of needs, formation, training, etc.).

On the labor market the price of the production factor "labor" is established and the rate and the level of employment and unemployment respectively. Therefore, the labor market is a key regulator of the cost of labor and employment, respectively unemployment.

In general, the labor market is defined as a crossing point of the demand and supply of labor or the potential of labor force and labor force needs of the different organizations of the national economy.

On the labor market, the individual is the one who offers their workforce, labor, i.e. their ability to produce. Those who offer their workforce or are looking for job are the people who are able-bodied and are currently willing to work. For example, the labor supply does not include persons of working age who are sick, disabled, or have lost completely their ability to work. It also excludes young people, children under a certain age (the one that is established in the national legislation) who are not entitled to work. Not all able-bodied persons offer their labor in the labor market, i.e. not everybody is willing to work. Individuals decide to offer their labor on the labor market mostly within their families, households. They are influenced by a number of factors and conditions.

Labor force is sought by its users, various enterprises, companies, institutions and other organizations. They are looking for labor with certain characteristics for specific jobs or positions. Their decision to seek work is determined by the status and tendencies in the development of the organization and the environment where it operates.

Supply and demand pursue certain interests and strategies, determined by the position of these two groups. These interests and strategies are the result of the typical structures of the households, human resources and enterprises, and they in turn are related to legislation, public policy and policy of allies of the social partnership.

The specific interests and strategies of demand and supply of labor arise from the structure of the three different levels of economic units (households and businesses), economic unions (trade unions and employers) and the state. From their interests and strategies arise the specific forms of directing the labor force to jobs, of supply and demand for labor.

The structure of the interests of an employee from a household: where no alternative other than employment is available (to be an entrepreneur housewife, sick, student, etc.) and when they need to sell their labor, following the relevant research on the choice of profession, they form the strategy and behavior to offer their labor. There are several typical interests:

- Inherent interest in the type of activity, in the workplace respectively. These interests are based on the aptitude and skills of the employees, which they try to utilize, to make use of their investment in education and training, knowledge and skills acquired. These interests are expressed in the supply of labor, work in the specific specialty field, professional direction and level of qualification of the different labor markets, each of which is relatively closed. A certain profession is selected. In other words, the driving force in the supply of labor is the professional realization.

- The most common interest is related to the payment for the labor provided and the receipt of income respectively. It is directed to provision of sufficient or the highest possible security of personal and family reproduction. In principle, this interest leads to behavior of labor supply, which is always directed towards jobs offering the relatively highest income. Such interest and behavior generally requires access to any unidentified and non-segmented labor market, where an activity or work is selected. Here the driving motive is the remuneration.

There is also an interest related to job security and insurance for risks at work. This also includes the interest in humane working conditions, lack of exploitation and premature physical and spiritual wearing out. This interest suggests behavior aimed at the search for safe and secured jobs and implies limited flexibility in terms of production, professional or regional mobility. The strategy for selection of an employee in the labor supply is generally directed to a particular type of enterprise.

The three groups of interests are in some contradiction, which does not allow predicting an explicit behavior. According to the prevalence of the separate interests, some of the described trends of behavior can be seen. 
Therefore, the motive (interest) to the remuneration itself cannot explain the behavior of supply. This is a shortcoming of the possible mechanism of remuneration in competition in the supply and demand for labor.

The employers (entrepreneurs, organizations) have similar interests. They can be grouped as follows:

- Interest in hiring employees with particular profession and level of qualification for the available jobs. This interest leads to demand for specialized labor force with the appropriate level of education, professional training and qualification. Here the interests of those who offer labor (employed or unemployed) and those who seek labor (organizations, employers) overlap in terms of quality. In practice, these one-way interests diverge in time or space, i.e. the periods of demand and supply of a particular labor do not coincide. This lack of coincidence can be in terms of location, settlement of demand and supply of labor. It is particularly typical for the so-called structural unemployment, as well as in case of a higher imbalance on the individual private labor markets. Therefore, the question if there is supply for the jobs available at any time, which is sufficient in quantity and corresponding to the type and level of qualification required, remains.

- Interest in reducing the costs of the production factor "labor". Salaries are income for the employee, but costs of production for the employer. These interests are generally in conflict relations.

- Interest in autonomy in relation to the environment, i.e. both in terms of the stock and the factor markets, including the labor market. This interest in autonomy in relation to the labor market leads to interest in the free control of the labor force in both recruitment and dismissal, and the internal production use. This interest is also in conflict with the interests of those who offer labor (the employees) in job security and decent working conditions.

These interests are in a certain contradiction with each other. The specific structure of the interests of a company depends exclusively on its technical and economic conditions, which is why one interest or another is more or less dominant. The situation in terms of labor supply is similar. Here the interests are determined by the situation in the household and / or family, its structure (employed - unemployed), the share of the employed persons in it and their income, values, etc.

The institutional structure of the labor market includes the state institutions; non-governmental organizations of employees (represented by trade unions) and employers' organizations (such as the Bulgarian Chamber of Commerce and Industry, Bulgarian Chamber of Commerce); legislation (law framework of the labor market), collective agreements, etc. On these so-called labor exchanges, the connection between those who supply labor and those who demand labor is made. They contribute to the proper functioning of the labor market and the implementation of the national and regional employment policy. The labor exchange is an intermediary unit, which facilitates labor transactions between employees and employers. It:

- Provides the connection between employers and employees;

- Accelerates the implementation of the transactions on the labor market through better information, guidance and advice to its participants;

- Provides information services to employers and employees in the supply and demand for work;

- Collects and analyzes information on the situation on the labor market - state, trends;

- Analyzes information on problems related to the relationship of supply and demand for labor, the expansion of employment with the inclusion of socially vulnerable groups;

- Creates conditions for the optimization of employment;

- Develops and implements special programs for retraining and training the qualification of the employees;

- Assists enterprises and organizations to create new jobs, etc.

The labor market also has certain social functions, expressed in the implementation of the national policy on employment and unemployment. It mixes the three main types of economic interests - those of the state, the employers and the employees, i.e. it operates on the principle of tripartism. It has all those characteristics typical also for the other exchanges (commodity, stock, currency), but at the same time has a number of distinguishing features. Its main differences stem from the specifics of the agreed "commodity" - the labor service.

The role of the labor market in the country is played by the National system of employment with its labor offices. The beginning of the labor market in the country is placed by Decree №57 of the Council of Ministers from December 1989. In 1990, a total of 119 labor offices are created to the municipal councils.

The public employment system includes: 
a/ at a national level

- National Council for Promotion of Employment, established 2002 as a permanent body for cooperation and consultation in the development of employment policy;

- National Advisory Council on vocational training;

- Employment Agency (National Employment Service) - 1991, which until 2002 controls the "Professional Qualification and Unemployment" fund, together with its social partners. By the Employment promotion act (2002) it receives status of an executive agency. It is a secondary administrator of the funds of the state budget to the MLSP.

b/ regional institutions:

- Governors and mayors;

- Permanent and temporary employment commissions;

- "Regional employment service" Directorates;

- "Labor office" Directorates and their branch offices.

Labor offices and their branch offices (remote workplaces) play a key role in the system of the labor market. They are the main structural unit performing various functions and responsibilities. The most important functions of the labor offices are related to the services they provide to those who seek job:

- Registration of the unemployed persons who are not employed but are actively looking for work;

- Information on job vacancies provided by the employers;

- Information for employees looking for job that corresponds to their qualifications and professional training;

- Organizing training and retraining of unemployed and others persons seeking a job change;

- Informing the unemployed and other persons seeking job vacancies, their orientation towards new career, new job, etc.

- Implementation of the social policy on employment to protect the unemployed through the implementation of measures and programs.

The most important services provided to the employers by the labor offices include:

- Providing information for persons who are actively seeking employment;

- Information on current programs and measures in the framework of the active policies on the labor market;

- Attracting employers to participate in programs and measures, etc.;

- Information on the preferences and bonuses in hiring unemployed; in opening new job positions and on participation in vocational training.

Private labor offices are another labor market institution that mediates the conclusion of the deal, the informing and hiring the employee by the employer and the conclusion of the employment contract. They perform functions similar to those of the labor offices at the state employment system: provide information on job vacancies, working conditions and payment, requirements to professional training and qualification of those who search job, etc. The services provided by "the private labor offices" are paid.

The mediation in employment is essential for the adaptation to the market conditions. The flexible use of the wide possibilities of the institutional units and organizations for information, guidance and consultation of those who supply and demand labor accelerates the realization of the transactions on the labor market (Terziev, Arabska, 2014; Terziev, 2015-b; Terziev, Arabska, 2016a).

Despite the quite pessimistic assessment of the perspectives for employment and unemployment, we should note that even in an unfavorable economic situation, despite the fact that people lose their jobs, new jobs are created as well, the unemployed find jobs and the employed change jobs. This shows that there are always both inflows and outflows of unemployment. They affect both the number of unemployed and the structural changes in the unemployment duration.

Rate of unemployment = inflow - outflow

To stabilize the unemployment, equality between the two flows is required. The unemployment increases if 
the inflow exceeds the outflow of unemployed. And vice versa, the unemployment will decrease, if the outflow is larger than the inflow of unemployed.

During the period 1992-1998, the inflows in the unemployment exceeded the outflows, which actually led to growth of the "stock" of unemployed.

How the accumulated "stock" affects the unemployment? To answer that question we will assume that the inflow is equal to the outflow, i.e. in such stationary model, the volume of unemployment will remain unchanged. We will present the unemployment rate in the following form:

$$
\frac{U}{N}=\frac{I}{N} / \frac{U}{I}
$$

where:

U - Unemployed

$\mathrm{N}$ - Active population

I - Inflow of unemployed

- Ratio of inflow to unemployment

$$
\frac{U}{N}
$$

- Average duration of unemployment

$$
\frac{U}{I}
$$

Therefore, in the stationary state model the following ratio between the number of unemployed, variable flows and duration of unemployment develops:

$$
U=I * D
$$

where:

$I=O$, i.e. the inflow is equal to the outflow,

D - Average duration of lack of work.

It follows from the formula above that the reduction of the outflow from the group of unemployed, caused, for example, by reduced demand for additional labor force, will not only lead to an increase in the unemployment rate, but will also increase its duration as it will take relatively more time for the unemployed to find a job and they will move to the group of those who do not have job for a longer period.

On the other hand, the significant inflow of newly unemployed (e.g. caused by massive discharge of labor force) will increase the unemployment rate, but will initially reduce the average duration of the unemployment as those who have lost their jobs will initially focus on the group of unemployed from a shorter period. In the absence of a corresponding outflow however, many of those people who have lost their jobs again will later be forced to remain unemployed for a constantly growing period. As a result, the overall picture of the unemployment duration will change in terms of both the average duration and the distribution of the unemployed according to the terms of unemployment.

As in the stationary model the ratio of inflow to employment is equal to the ratio of outflow from unemployment, the average duration of unemployment can be presented as a quantity opposite to the ratio of outflow from unemployment.

$$
\frac{U}{N}=K_{i} / K_{o}
$$


where:

Ki - Ratio of inflow to unemployment

K0- ratio of outflow of unemployment

It follows from the last ratio that the increase of the unemployment rate arithmetically can be explained by both the increase of the ratio of the inflow and the decrease of the ratio of the outflow (i.e. with the increase of its duration).

The characteristics of the inflow to and outflow from the unemployment and its duration allow us to understand the differences between the different types of labor markets. In some cases, unemployment is characterized by relatively small flows, with low level, but long duration. In other cases, due to the greater dynamics of the labor market, both the inflows and the outflows prove to be powerful enough to prevent the formation of a "permanent" stock of long-term unemployment. Therefore, the average duration of unemployment here is significantly lower, even when the unemployment rate is too high (Terziev, Georgiev, 2018e-f; Terziev, Arabska, 2014; Terziev, 2015-b; Terziev, Arabska, 2016a).

Table 1. contains a short characteristic of certain types of labor markets. The most dynamic are the labor markets in the US and Canada, as they are characterized by high indexes of the inflow to and outflow from unemployment, short duration and average level of unemployment. In our country, the relatively high intensity of the rate of inflow to unemployment is combined with a low rate of outflow from unemployment, as well as with too high and increasing duration.

Table 1. Types of labor markets

\begin{tabular}{|c|c|c|c|c|}
\hline & $\begin{array}{l}\text { Unemployment rate } \\
\qquad(\mathrm{U} / \mathrm{N})\end{array}$ & $\begin{array}{l}\text { Ratio of inflow to } \\
\text { unemployment } \\
\qquad(\mathrm{I} / \mathrm{N})\end{array}$ & $\begin{array}{c}\text { Ratio of outflow from } \\
\text { unemployment } \\
(\mathrm{I} /(\mathrm{U} / \mathrm{N}))\end{array}$ & $\begin{array}{l}\text { Duration } \\
\quad(\mathrm{U} / \mathrm{I})\end{array}$ \\
\hline Belgium & 8.3 & 0.2 & 0.02 & 50 \\
\hline France & 11.1 & 0.6 & 0.1 & 21 \\
\hline Germany & 6.6 & 0.4 & 0.1 & 16 \\
\hline Denmark & 9.4 & 0.8 & 0.1 & 11 \\
\hline UK & 9.1 & 0.9 & 0.1 & 10 \\
\hline \multicolumn{5}{|c|}{ High flow, short duration } \\
\hline Australia & 7.8 & 1.4 & 0.2 & 6 \\
\hline Canada & 8.3 & 2.6 & 0.3 & 3 \\
\hline USA & 5.8 & 2.2 & 0.4 & 3 \\
\hline \multicolumn{5}{|c|}{ Low flow, short duration } \\
\hline Finland & 5.3 & 1.1 & 0.2 & 5 \\
\hline Norway & 3.3 & 1.1 & 0.3 & 3 \\
\hline Sweden & 1.6 & 0.5 & 0.3 & 3 \\
\hline
\end{tabular}




\section{CONCLUSION}

Knowing the types of labor markets according to the intensity of the flows and the unemployment duration is of crucial importance for determining the means of overcoming the unemployment. The intensity of the inflow to unemployment depends mainly on the macroeconomic employment opportunities. If the conditions are unfavorable, the number of jobs, including job vacancies, goes down. The inflow to unemployment goes up. In the event that the increase of the unemployment is explained namely by the growth of the inflow, then its decrease (stabilization of the employment rate at the expense of reduction of working time for example, generating jobs in new sectors in which the employees transfer to, avoiding unemployment etc.) becomes a priority of policy. However, at the same time there is also another factor on the labor market - the duration. Moreover, the duration of unemployment is not in a direct relation to the number of job vacancies. For some groups of unemployed the probability to find a job is always greater than for others (Terziev, Arabska, 2014; Terziev, 2015-b; Terziev, Arabska, 2016a).

\section{REFERENCE LIST}

Georgiev, Marin. (2016). Obshtestvenoto i ikonomichesko razvitie v konteksta na sotsialnite politiki. // Spisanie za nauka „Novo znanie“. Visshe Uchilishte po Agrobiznes i Razvitie na Regionite, 5, 2016, N 4, str. 26-41, ISSN 2367-4598 (Online), (Print) ISSN $1314-5703$ (Георгиев, Марин. Общественото и икономическо развитие в контекста на социалните политики. // Списание за наука „Ново знание“. Висше училище по агробизнес и развитие на регионите, 5, 2016, N 4, стр. 26-41, ISSN 2367-4598 (Online), (Print) ISSN 1314-5703.

Georgiev, Marin. (2017). Sbalansirovannaya karta kak alyternativa malogo biznesa. // Innovatsionnie tehnologii v nauke novogo vrmeni, Sbornik statey Mezhdunarodnoy nauchno - prakticheskoy konferentsii 1 fevralya 2017 g., Ufa NITS AETERNA, Chasty 1, 2017, s. 43-49, ISBN 978-5-00109004-5, ISBN 978-5-00109-007-6 (Георгиев, Марин. Сбалансированная карта как альтернатива малого бизнеса. // Инновационніе технологии в науке нового врмени, Сборник статей Международной научно - практической конференции 1 февраля 2017 г., Уфа НИЦ АЭТЕРНА, Часть 1, 2017, с. 43-49, ISBN 978-5-00109-004-5, ISBN 978-5-00109-007-6).

Georgiev, Marin. (2017a). Impacts of active social programs on labor market. // Mezhdunarodnayy nauchnayy zhurnal «Innovatsionnaya nauka». NITS Aeterna, N 02-1, 2017, pp. 139-143, ISSN 24106070 (Georgiev, Marin. Impacts of active social programs on labor market. // Международный научный журнал «Инновационная наука». НИЦ Аэтерна, N 02-1, 2017, pp. 139-143, ISSN $2410-$ 6070).

Terziev, V., Kanev, D. (2019). Modern developments in behavioral economics. // Smart Technologies and Innovations in Design for Control of Technological Processes and Objects: Economy and Production Proceeding of the International Science and Technology Conference „FarEastCon-2018“ Volume 138, October 2-4, 2018, Vladivostok, Russian Federation, pp. 10-23, 2019, (Print) ISBN978-3-030-15576-6, (Online) ISBN978-3-030-15577-3.

Terziev, Venelin. (2019a). Provision of integrated employment and social assistance services in Bulgaria. // Smart Technologies and Innovations in Design for Control of Technological Processes and Objects: Economy and Production Proceeding of the International Science and Technology Conference „FarEastCon-2018“ Volume 138, October 2-4, 2018, Vladivostok, Russian Federation, pp. 24-39, 2019, (Print) ISBN978-3-030-15576-6, (Online) ISBN978-3-030-15577-3.

Terziev, Venelin. (2019b). Problems of control in the social sphere. // INTCESS 2019- $6^{\text {th }}$ International Conference on Education and Social Sciences, 4-6 February, 2019, Dubai, International Organization Center of Academic Research, Istanbul, Turkey, pp. 577-593, ISBN: 978-605-82433-5-4.

Terziev, Venelin. (2019c). The criterion "competence" in the economic sector. // INTCESS 2019- $6^{\text {th }}$ International Conference on Education and Social Sciences, 4-6 February, 2019, Dubai, International Organization Center of Academic Research, Istanbul, Turkey, pp. 1241-1247, ISBN: 978-605-824335-4.

Terziev, Venelin. (2019d). Social policy and labor market development in Bulgarian transition period. // INTCESS 2019- $6^{\text {th }}$ International Conference on Education and Social Sciences, 4-6 February, 2019, 
IJASOS- International E-Journal of Advances in Social Sciences, Vol. V, Issue 14, August 2019

Dubai, International Organization Center of Academic Research, Istanbul, Turkey, pp. 703-714, ISBN: 978-605-82433-5-4.

Terziev, Venelin. (2019e). Theoretical basis of development of labor market and social policy in the republic of Bulgaria. // INTCESS 2019- $6^{\text {th }}$ International Conference on Education and Social Sciences, 4-6 February, 2019, Dubai, International Organization Center of Academic Research, Istanbul, Turkey, pp. 715-726, ISBN: 978-605-82433-5-4.

Terziev, Venelin. (2019f). The problem of social efficiency- Indicators for social efficiency. // INTCESS 2019$6^{\text {th }}$ International Conference on Education and Social Sciences, 4-6 February, 2019, Dubai, International Organization Center of Academic Research, Istanbul, Turkey, pp. 669-678, ISBN: 978605-82433-5-4.

Terziev, Venelin. (2019g). Experiencing social policy development and efficiency measurment. // INTCESS 2019- $6^{\text {th }}$ International Conference on Education and Social Sciences, 4-6 February, 2019, Dubai, International Organization Center of Academic Research, Istanbul, Turkey, pp. 679-686, ISBN: 978605-82433-5-4.

Terziev, Venelin. (2019h). Efficiency and assessment of social technology. // INTCESS 2019- th $^{\text {th }}$ International Conference on Education and Social Sciences, 4-6 February, 2019, Dubai, International Organization Center of Academic Research, Istanbul, Turkey, pp. 687-694, ISBN: 978-605-82433-5-4.

Terziev, Venelin. (2019i). Conceptual framework of social adaptation. // INTCESS 2019- $6^{t} h$ International Conference on Education and Social Sciences, 4-6 February, 2019, Dubai, International Organization Center of Academic Research, Istanbul, Turkey, pp. 494-503, ISBN: 978-605-82433-5-4.

Terziev, Venelin. (2019j). The dependence social adaptation- socialization. // INTCESS 2019- $6^{\text {th }}$ International Conference on Education and Social Sciences, 4-6 February, 2019, Dubai, International Organization Center of Academic Research, Istanbul, Turkey, pp. 478-485, ISBN: 978-605-82433-5-4.

Terziev, Venelin. (2019k). Social activity and human resources as social development factors. // INTCESS 2019- 6th International Conference on Education and Social Sciences, 4-6 February, 2019, Dubai, International Organization Center of Academic Research, Istanbul, Turkey, pp. 546-553, ISBN: 978605-82433-5-4.

Terziev, Venelin. (2018). The active model of a social programme and its strategic advantage . // ADVED 2018- $4^{\text {th }}$ International Conference on Advances in Education and Social Sciences Abstracts \& Proceedings, 15-17 October 2018- Istanbul, Turkey, International Organization Center of Academic Research, www.ocerints.org, Istanbul, Turkey, 2018, pp. 189-203, ISBN: 978-605-82433-4-7.

Terziev, Venelin. (2018a). Active social programs development in Bulgaria: contemporary challenges and social management instruments. // ADVED 2018- $4^{\text {th }}$ International Conference on Advances in Education and Social Sciences Abstracts \& Proceedings, 15-17 October 2018- Istanbul, Turkey, International Organization Center of Academic Research, www.ocerints.org, Istanbul, Turkey, 2018, pp. 149-163, ISBN: 978-605-82433-4-7.

Terziev, Venelin. (2018b). Social assistance services and integrated employment in Bulgaria. // ADVED 2018- 4th International Conference on Advances in Education and Social Sciences Abstracts \& Proceedings, 15-17 October 2018- Istanbul, Turkey, International Organization Center of Academic Research, www.ocerints.org, Istanbul, Turkey, 2018, pp. 164-177, ISBN: 978-605-82433-4-7.

Terziev, Venelin. (2018c). Impact of the labor market policies for ensuring employment. // ADVED 2018-4th International Conference on Advances in Education and Social Sciences Abstracts \& Proceedings, 1517 October 2018- Istanbul, Turkey, International Organization Center of Academic Research, www.ocerints.org, Istanbul, Turkey, 2018, pp. 178-188, ISBN: 978-605-82433-4-7.

Terziev, Venelin. (2018d). Importance of human resources to social development. // ADVED 2018- $4^{\text {th }}$ International Conference on Advances in Education and Social Sciences Abstracts \& Proceedings, 1517 October 2018- Istanbul, Turkey, International Organization Center of Academic Research, www.ocerints.org, Istanbul, Turkey, 2018, pp. 204-212, ISBN: 978-605-82433-4-7.

Terziev, V., Georgiev, M. (2018e). A strategic framework for the development of social entrepreneurship in Bulgaria. // Knowledge - International Journal, August 2018, Institute of Knowledge Management, Skopje, Macedonia, 25, 2018, N 1, pp. 23-34, ISSN 1857-923X (for e-version), ISSN 2545 - 4439 (for printed version).

Terziev, V., Georgiev, M. (2018f). Support for the development of social entrepreneurship in Bulgaria. // 
Knowledge - International Journal, September, 2018, Institute of Knowledge Management, Skopje, Macedonia, 26, 2018, N1, pp.57-74, ISSN 1857-923X (for e-version), ISSN 2545 - 4439 (for printed version).

Terziev, V., E., Arabska. (2014). Assessment of active social policies' impacts on labor market in the Republic of Bulgaria. Kolektivnaya monografiya "Sotsialyno-ekonomicheskie i pravovay razvitiya ekonomiki“, Ufa, Aeterna. Rossiya, 2014. ISBN 978-5-906769-97-8, str. 3-57 (Terziev, V., E. Arabska. (2014). Assessment of active social policies' impacts on labor market in the Republic of Bulgaria. Колективная монография „Социально-экономические и правовы развития экономики“, Уфа, Аэтерна. Россия, 2014. ISBN 978-5-906769-97-8, стр. 3-57).

Terziev, Venelin. (2015). Impact of active social policies and programs in the period of active economic transformations in Bulgaria, „East West” Association for Advanced Studies and Higher Education, Vienna, 2015, ISBN 78-3-903063-44-0, $434 \mathrm{p}$.

Terziev, Venelin. (2015a). Assessment of active social policies impact of social policies on transformation processes in bulgarian economy, Moscow, 2015, Publisher „Перо“, 110 p.

Terziev, Venelin. (2015b). Opportunities for improving the efficiency of the social adaptation of servicemen discharged from military service in Bulgaria:- Novosibirsk: Publisher CRNS, 2015. ISBN 978-5-00068402-3, 270 p.

Terziev, V., E., Arabska. (2016a). Effektivnoe vliyanie na raynok truda posredstvom uluchsheniya realizatsii sotsialynoy politiki. Novosibirsk: Izdatelystvo TSRNS, 2016. ISBN 978-5-00068-496-2, $312 \mathrm{str}$ (Терзиев, В., Е. Арабска. (2016а). Эфрфективное влияние на рынок труда посредством улучшения реализации социальной политики. Новосибирск: Издательство ЦРНС, 2016. ISBN 978-5-00068-496-2, 312 стр). 